\title{
Queer Lovers and Hateful Others
}

https://doi.org/10.51897/interalia/JLOX7075

\section{Mateusz Świetlicki}

Uniwersytet Wrocławski

Recenzja: Jin Haritaworn, Queer Lovers and Hateful Others. Regenerating Violent Times and Places, London: Pluto Press 2015, s. 237

Chociaż książka Jin Haritaworn poświęcona jest badaniu przestrzeni miejskiej Berlina, to jej tematyka ma bardzo aktualny, nowatorski i transnacjonalny charakter. Zestawienie ewolucji stosunku (bio)władzy do środowisk LGBT z kreowanymi na naszych oczach rasistowskimi dyskursami dotyczącymi imigrantów i uchodźców wydaje się obecnie jeszcze bardziej aktualne niż w roku wydania Queer Lovers and Hateful Others. Recenzowana monografia pokazuje, że Haritaworn należy do grona najbardziej nowatorskich badaczy gender i queer studies. Wydana w serii „Decolonial Studies, Postcolonial Horizons" wydawnictwa Pluto, książka została podzielona na wstęp, wprowadzenie, cztery tematyczne rozdziały, podsumowanie i epilog. Do pracy dołączono szczegółową bibliografię, spis ilustracji oraz indeks nazwisk.

W obszernym wstępie obok zarysu ogólnej tematyki monografii i przedstawienia treści jej poszczególnych komponentów, wprowadzone zostały narzędzia metodyczne i najważniejsze terminy teoretyczne. Czytelnikowi przedstawiony został koncept queerowych regeneracji (queer regenerations), swoistych transformacji stosunku neoliberalnych władz do osób LGBT. Wspomniano również o wyłonieniu się nowego „Innego", homofobicznego i transfobicznego imigranta1. Czytamy, że obok takich terminów jak przemoc, patriarchat, segregacja rasowa, gentryfikacja i neoliberalna rekonstrukcja, to właśnie Muzułmanin-homofob staje się nowym, demonizowanym słowem-wytrychem. Obok niego wyłania się natomiast nowy podmiot LGBT - zasługujący na ochronę i zapewnienie bezpieczeństwa reprezentant białej klasy średniej, wykorzystywany jako narzędzie polityczne. Analizując zmianę dyskursów o przestrzeni miejskiej Berlina Haritaworn skupia się nie tylko na teraźniejszości - sięga też do historii i nakreśla jej związki z obecną sytuacją osób LGBT. Zwracając uwagę na wszechobecny, jednostkowy i często transparentny charakter rasizmu, pokazuje jego występowanie również poza dyskursem skrajnej prawicy i neofaszystów. Wykorzystując wprowadzony przez brytyjskiego marksistę Erica Hobsbawma termin "wynaleziona tradycja” (invented tradition), homonazjonalizm Jasbir Puar oraz teorię postkolonialną (w tym wybrane pisma Edwarda Said, Niry Yuval-Davis, czy Sunery Thobani), Haritaworn we wstępie Queer Lovers and Hateful Others pokazuje, jak podmiot LGBT staje się strażnikiem granic na nowo definiowanej normatywności. Chociaż monografia skupia się na Berlinie i rozmowach przeprowadzanych z jego mieszkańcami, nie sposób nie zauważyć w niej uniwersalnych odniesień globalnych.

\footnotetext{
${ }^{1}$ Nie sposób w tym miejscu nie zauważyć odniesień do relacji biowładzy i rasizmu Foucaulta. Zob. M. Foucault, Trzeba bronić spoteczeństwa. Wykłady w Collège de France, 1976, przeł. M. Kowalska, Warszawa 1998, s. 237-260.
} 
Pierwszy rozdział stanowi próbę umiejscowienia problematyki monografii i przedstawienia czytelnikowi historii berlińskich dzielnic: robotniczych Kreuzberg i Neukölln (gdzie doszło do queerowej gentryfikacji) oraz pierwszej gejowskiej - Schöneberg. Haritaworn powołuje się na publikacje dotyczące związku gentryfikacji z homogenizacją środowiska LGBT, homonormatywnością (Lisa Duggan), globalizacją i turystyką. Na przykładzie dzielnicy Kreuzberg pokazano przenikanie się przemocy, patriarchatu i homofobii, jak również wyłonienie się gruntu do queerowych regeneracji. Osoby nie-białe (w tym nie-białe osoby LGBT) stają tu w kontraście z białymi, homonormatywnymi podmiotami LGBT. Queerowa gentryfikacja opisana jest w sposób niestereotypowy i wielowymiarowy.

Drugi, wnikliwy rozdział zatytułowany Love poświęcono szczegółowemu opisowi zmiany dyskursu dotyczącego LGBT. Niegdyś kryminalizowane i patologizowane, obecnie fizyczne przejawy relacji osób nieheteroseksualnych goszczą w kolorowych magazynach i w reklamach zamieszczanych w zdegenerowanych dzielnicach. Dowiadujemy się, że ma to na celu nauczenie imigrantów tolerancji i szacunku do odmienności. Haritaworn podkreśla homonormatywny charakter tych obrazów, doskonale wpisujących się w globalną kulturę konsumpcjonizmu, wskazując jednocześnie na kolonialną ewolucję od degenerata-sodomity do wrażliwego i wymagającego ochrony homo(normatywnego)seksualisty. Uroczy homoseksualista musi jednak być młodym, sprawnym i białym konformistą. W rozdziale pokazano występujący w tym dyskursie pozytywny stosunek do osób transseksualnych, których ciała stanowią wyznacznik poziomu tolerancji niemieckiego społeczeństwa. Osoby transseksualne przyjmują istotną rolę ofiary przemocy uwarunkowanej nienawiścią do nowego Innego. Nie-białe osoby LGBT stają na rozdrożu - w takim systemie nie mogą w pełni stać ani po stronie ofiar, ani ciemiężycieli.

Uzupełnieniem Love jest kolejny rozdział, zatytułowany Hate. Omówiono w nim obraz Innego, bez którego nie mogłoby dojść do wspomnianej już homonormalizacji środowiska LGBT. Haritaworn wskazuje na szereg globalnych technik dyskursywnych stosowanych w celu zdyskredytowania najbiedniejszych środowisk osób nie-białych. Dzięki przywołaniu medialnych reprezentacji muzułmanów w niemieckiej telewizji i tabloidach, w rozdziale pokazano stopniowe przenikanie się, a następnie pokrywanie postaci przestępy/degenerata i muzułmanina. Haritaworn podkreśla też wszechobecną rolę mowy nienawiści w konstruowaniu mitu Innego.

Czwarty, najkrótszy rozdział zatytułowany Queer Nostalgia pokazuje ulotność i tymczasowość dyskursu. Haritaworn przypomina czytelnikowi zmieniający się w czasie stosunek władz i społeczeństwa do osób queer, odwołując się do Holocaustu i wykluczenia, a następnie stopniowego włączania osób nieheteroseksualnych w poczet upamiętnianych ofiar. Pokazuje tu, jak wspominanie zbrodni nazistowskich może uaktywnić niechęć wobec konkretnej grupy społecznej. Zwraca też uwagę na kwestię przenikania się rasizmu i homofobii.

Lektura monografii Jin Haritaworn jest warta polecenia nie tylko osobom zajmującym się socjologią, badaniami genderowymi i queerowymi, czy problematyką rasizmu - może stanowić ciekawą pozycję dla badaczy niemal wszystkich dyscyplin. Przeszkodą w odbiorze książki może być jednak trudny i niejasny język, jak również styl Haritaworn. Queer Lovers and Hateful Others oparta jest na rzetelnie 
opracowanym materiale teoretycznym i praktycznym - na szczególną uwagę zasługuje opracowanie rozmów z mieszkańcami Berlina. Z uwagi na ściśle określony geograficznie zakres badań książka ma pozornie ograniczony, lokalny charakter, jednak w rzeczywistości porusza problemy aktualne i globalne. Tak zwany "kryzys uchodźców” w wielu europejskich krajach obudził radykalnie prawicowe ruchy narodowościowe, które swój neonazistowski dyskurs budują wokół propagowania nienawiści do Innego. Chociaż starzy Inni różnią się w zależności od kraju (zazwyczaj są to osoby LGBT, feministki, innowiercy, najbiedniejsi) to tymi nowymi Innymi są zawsze uchodźca (muzułmanin) i imigrant (muzułmanin, ale bywa też Polak - np. w Wielkiej Brytanii - i Ukrainiec - w Polsce). Porównując wielonarodowościowy Berlin z sytuacją panująca obecnie w stosunkowo monoetnicznej Polsce, można się zastanawiać, czy nowi Inni (muzułmanie, Ukraińcy) doprowadzą do homonormatywizacji środowiska LGBT, czy może starzy i nowi Inni będą koegzystować jako wspólni wrogowie ojczyzny i polskości. 